\title{
MINERAL RESOURCE POTENTIAL OF THE CACTUS SPRING ROADLESS AREA, RIVERSIDE COUNTY, CALIFORNIA
}

\section{SUMMARY REPORT}

\author{
By \\ Jonathan C. Matti, Brett F. Cox, Robert E. Powell, \\ and Howard W. Oliver \\ U.S. Geological Survey \\ and
}

Lueia Kuizon

U.S. Bureau of Mines

\section{STUDIES RELATED TO WILDERNESS}

Under the provisions of the Wilderness Act (Public Law 88-577, September 3, 1964) and the Joint Conference Report on Senate Bill 4, 88th Congress, the U.S. Geological Survey and the U.S. Bureau of Mines have been conducting mineral surveys of wilderness and primitive areas. Areas officially designated as "wilderness," "wild," or "canoe" when the act was passed were incorporated into the National Wilderness preservation System, and some of them are presently being studied. The act provided that areas under consideration for wilderness designation should be studied for suitability for incorporation into the wilderness System. The mineral surveys constitute one aspect of the suitability studies. The act directs that the results of such surveys are to be made available to the public and be submitted to the President and the Congress. This report discusses the results of a mineral survey of the Cactus Spring Roadless Area (A5-188), San Bernardino National Forest, Riverside County, California. The Cactus Spring Roadless Area was classified as a further planning area during the Second Roadless Area Review and Evaluation (RARE II) by the U.S. Forest Service, January, 1979.

\section{SUMMARY}

Geologic, geochemical, and geophysical studies, together with an investigation of mines, claims, and prospects, indicate that the Cactus Spring Roadless Area has no demonstrated or inferred mineral resources 1 or energy resources. Throughout most of the roadless area, we did not observe indications of potential for these resources. However, a metasedimentary pendant in the southwestern part of the roadless area has low potential for low-grade tungsten resources. At nearby localities outside of the roadless area, the tungsten-bearing mineral scheelite has been identified in small-scale tactite lenses where metasedimentary rocks have been intruded by granitoid rock. In the Cactus Springs Roadless Area, undiscovered occurrences of tungsten within the zone of low potential most likely are small scale, and probably will contain low-grade tungsten similar to that occurring in tactite lenses identified elsewhere in the Santa Rosa Mountains.

Bodies of marble (metamorphosed limestone and dolomite) in the northern part of the roadless area constitute possible nonmetallic resources. The marble bodies could provide (1) crushed aggregate for roofing granules, road base, riprap, and decorative stone, and (2) lime and magnesium for cement and for industrial and manufacturing applications. Many marble units are interlayered complexly with non-carbonate metasedimentary rocks, have variable magnesium content, and contain variable amounts of impurities in the form of chert nodules, calc-silicate minerals, and iron. Other marble units are monolithologic and consist of relatively pure high-calcium carbonate. We have not evaluated the quality, quantity, or applicability of resources represented by the metacarbonate rocks.

\section{INTRODUCTION}

The Cactus Spring Roadless Area (A5-188) is located in the Santa Rosa Mountains, about $25 \mathrm{mi}$ southeast of Palm Springs and about $10 \mathrm{mi}$ south of Palm Degsert, Calif. (fig. 1). The roadless area consists of about $30 \mathrm{mi}^{2}$ of land within the San Bernardino National Forest, and includes rugged mountainous terrain covered with coniferous forest and dense chaparral as well as rolling high-desert terrain that supports a blend of desert scrub and pinyon-juniper woodland. Topographic relief within the study area ranges from about $2,000 \mathrm{ft}$ to about $7,600 \mathrm{ft}$; prominent summits in the vicinity include Martinez Mountain $(6,562 \mathrm{ft})$, Toro Peak $(8,716 \mathrm{ft})$, and Santa Rosa Mountain $(8,070 \mathrm{ft})$. Two major stream drainages bisect the study area: Horsethief Creek flowing northwestward into Deep Canyon, and an unnamed perennial stream flowing southeastward through Martinez Canyon. Access to the roadless area is limited because it is surrounded almost entirely by rugged ground that has no roads and few established trails. Limited access is provided by the Cactus Spring foot trail that originates near California State Highway 74 at the northwest corner of the roadless area.

\section{Purpose and scope}

This report summarizes the results of geologic, geochemical, and geophysical surveys conducted in the Cactus Spring Roadless Area by the U.S. Geological Survey and an investigation of mines, prospects, and mineralized areas conducted by the U.S. Bureau of Mines. The purpose of

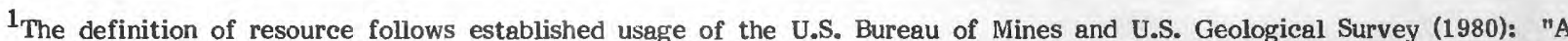
concentration of naturally occurring solid, liquid, or gaseous material in or on the Earth's crust in such form and amount that economic extraction of a commodity from the concentration is currently or potentially feasible." Defined in this broad fashion, a resource can contain extractable materials (reserves) that can be developed now, and (or) additional material (marginal reserves, subeconomic resources) that feasibly may be developed in the future under more favorable market conditions and (or) with more advanced technological capability.
} 
this study is to provide a mineral-resource basis for land-use decisions regarding the study area, and to target areas that are more suitable than others for additional mineral resource investigations. To achieve these goals, this study is designed to distinguish areas of lesser or greater resource potential based on differences in the type, scale, and degree of mineral concentration.

The techniques used in this investigation permit two types of reconnaissance evaluation: (1) where appropriate, we can estimate measured, indicated, or inferred resources for mines and prospects identified within the study aree (mineral resource terminology follows the usage of U.S. Bureau of Mines and U.S. Geological Survey, 1980); (2) for geologic terranes that have no identified resources, we can judge whether high, moderate, or low potential exists for undiscoverved metallic, nonmetallic, or energy resources based on the strength of the aveilable evidence. The reconnaissance nature of this investigation limits our ability to make definitive statements about the geologic setting or resource content of known or suspected mineral occurrences. We can identify areas that have potential for additional resource studies, and we can describe generalized geologic environments for particular minerals that are known or suspected to exist. In addition, for geologic terranes that have no identified resources, we can provide limited judgments about the most likely scale of occurrence for undiscovered minerals based on what we know about the geologic setting and geochemical or geophysical signatures, and based especially on analogy with known occurrences in similar geologic settings elsewhere in the region. However, for mineral occurrences newly identified by us or indicated indirectly by geochemical or geophysical data, we can not document the quality and quantity of resources contained in such occurrences. Follow up studies in the Cactus Spring Roadless Area-involving additional geologic mapping, more detailed geochemical surveys of bedrock and streamsediments, and drilling-would be necessary to document the geologic setting, extent, and grade of metallic, nonmetallic, or energy resources that might be present. Any resource potential we have assigned could be upgraded or downgraded based on new information or future changes in resource requirements.

\section{Previous studies}

Rocks in the Cactus Spring Roadless Area previously have not been studied in detail. Fraser (1931) provided an early investigation of the region, and Wright (1946) discussed some of the rocks in the study area. Sharp (1979) discussed thrust faults and other structures that have deformed rocks in the Santa Rosa Mountains. Sims (1960) and Parcel (1981) studied rocks adjacent to the roadless area, and Brown (1980, 1981) described the geology and resources of rocks in the southeastern San Jacinto Mountains that are similar to those in the roadless area

\section{GEOLOGIC SETTING}

The Cactus Spring Roadless Area is underlain by surficial deposits of Quaternary and older(?) age and by crystalline bedrock of Mesozoic and older age. The surficial deposits occur mainly in stream valleys that contain thin deposits of sand and gravel; landslides occur on some hillslopes, especially in the vicinity of Martinez Mountain The roadless area is underlain mainly by crystalline bedrock that consists of plutonic igneous rocks and metamorphosed sedimentary rocks (fig. 2).. The crystalline units have been deformed during at least two major events (Sharp, 1979): (1) a period of intense ductile shearing that stretched and squeezed the rocks and produced foliated and layered fabrics (mylonitic fabrics); and (2) a period of brittle deformation during which different rock types were juxtaposed by largescale lateral movements on low-angle faults like the Palm Canyon, Martinez Mountain, and Deep Canyon faults.

The oldest rocks in the area are metasedimentary units that include hornfels, biotite schist and phyllite, gneiss, metaquartzite, and calcareous and dolomitic marble. These rocks represent accumulations of clay, silt, sand, and calcareous sediment that were deposited in the sea, probabiy during the Paleozoic and (or) late Precambrian (Miller and others, 1983, and Miller and Dockum, 1983, document this age span for similar metasedimentary rocks elsewhere in southern and Baja California). However, the exact age of the original sediments is unknown, and they may have been deposited as late as the Mesozoic. During the late Mesozoic, the sedimentary rocks were intruded by large plutonic bodies of granitic magma. High temperature and pressure associated with these igneous events converted the sedimentary rock to schist, phyllite, metaquartzite, gneiss, and marble by metamorphic processes that recrystallized the sedimentary rocks, folded and sheared-out the sedimentary layering, and produced new mineral assemblages of the amphibolite facies.

The igneous bodies produced during these plutonic events include various types of granitoid rock that crop out over much of the Cactus Spring Roadless Area. These granitoid rocks can be grouped into biotite-bearing units and biotite-hornblende-bearing units. We have not documented the intrusive age relations between all of these plutonic rocks. However, most of the biotite-hornblende units appear to be older than the biotite-bearing units.

Light-colored granitoid rocks are the most abundant plutonic rock type, and consist of biotite-bearing granodiorite, monzogranite, and tonalite (rock classification follows Streckeisen, 1973). In the lower and upper plates of the Palm Canyon fault, these rocks have variable textures and compositions. A sheetlike body of very leucocratic, garnetiferous, muscovite-biotite monzogranite on the north flanks of Toro Peak is a distinctive lithology that contrasts with the more abundant one-mica biotite granitoids; similar units of leucocratic two-mica monzogranite occur in the upper plate of the Palm Canyon fault, where the monzogranite consists of irregularly-shaped bodies and lenses. Most bodies of leucocratic monzogranite are characterized (1) by the local occurrence of garnet and both muscovite and biotite, and (2) by spatial association of the monzogranite with lenses and bodies of high-grade metasedimentary schist and gneiss that exhibit evidence of melting and assimilation. Granitoid rocks in the upper plate of the Martinez Mountain and Deep Canyon faults are more homogeneous compositionally and texturally than plutonic rocks below the fault, and are dominated by slightly foliated granodiorite that locally contains abundant sphene (a calcium-titanium mineral).

Dark-colored granitoid rocks in the roadless area include mafic biotite granodiorite and biotite-hornblende monzodiorite, tonalite, and quartz diorite. These rocks occur mainly in the upper plate of the Palm Canyon fault, where a large body of biotite-hornblende quartz diorite is the most abundant lithology. In the lower plate of the Palm Canyon fault, the mesocratic plutonic rocks are not so abundant and occur mainly as elongate bodies of monzodiorite and quartz diorite directly beneath the thrust.

\section{Mylonitization and low-angle faulting}

Toward the end of the plutonic and metamorphic events, some parts of the region were subjected to intense ductile shearing that flattened and squeezed the rocks, resulting in a variety of deformational fabrics. Rocks in the southwest part of the Cactus Spring Roadless Area, in the vicinity of Toro Peak, generally escaped this deformation, or only were affected mildly by it as evidenced by slight textural foliation. However, northeastward toward Horsethief Creek, the rocks progressively display increasing evidence of shearing. In the deformed zone, the rocks are strongly foliated and mylonitized and exhibit a conspicuous northeast-plunging lineation that consists of biotite and quartz concentrations that have been streaked out down the dip of the northeast-dipping foliation. Locally, the mylonitic fabrics are so well developed that they obscure the original plutonic or metamorphic aspect of the rocks. The leucocratic, garnetiferous two-mica monzogranite on the north flanks of Toro Peak exhibits the mylonitic foliation especially well. However, the most intensely deformed rocks are a narrow belt of dark-colored, fine-grained mylonitic quartz diorite that occurs beneath the Palm Canyon fault. In 
the upper plate of the fault the rocks also are foliated and mylonitized, although not so intensely as the unit of mylonitic quartz diorite in the lower plate. In the upper plate, garnetiferous leucogranite and siliceous metasedimentary rocks generally are the most intensely mylonitizied rock units.

After the episodes of ductile deformation, episodes of brittle deformation produced low-angle faults that broke the rocks into slabs or plates and carried these plates laterally. These low-angle faults include the Palm Canyon, Martinez Mountain, and Deep Canyon faults (fig. 2). Some faultbounded plates may have been displaced only a short distance. However, other plates may have been displaced a few miles or even a few tens of miles laterally, as suggested by relationships on Martinez Mountain where the Martinez Mountain fault system has juxtaposed a plate of relatively undeformed granitic rock over a plate of highly deformed and mylonitized granitic and metasedimentary rocks. The brittle faults and fault zones are characterized by narrow to wide zones of sheared, crushed, and fractured rock that contain one or more distinct fault surfaces, and that exhibit cataclastic textures and pseudotachylite (Sharp, 1979). The fault zones exhibit chloritic alteration, and locally contain pink veinlets and stains that appear to be potassium feldspar.

Sharp (1979) suggested that the episodes of ductile and brittle deformation were related temporally and structurally, and he suggested a late Mesozoic age for both styles of deformation. Dokka and Frost (1979) report radiometric ages of about 63 m.y.B.P. from mylonitic granitoid rocks; this value may reflect a cooling age for the rocks following their mylonitic deformation. We have contributed no new data regarding the age of deformation. However, because the mylonitic foliation is truncated by the low-angle faults and because the structural contrast between ductile and brittle styles of deformation is so marked, we suspect that the brittle phase of low-angle faulting is much younger than the ductile deformation, and has no direct relationship to it structurally.

\section{GEOLOGY, GEOCHEMISTRY, AND GEOPHYSICS PERTAINING TO MINERAL RESOURCE ASSESSMENT}

\section{GEOLOGY}

\section{Metallic and Nonmetallic Mineralization}

Although geologic environments that commonly are favorable for the development of mineral deposits occur in the Cactus Spring Roadless Area, we did not observe field evidence for significant occurrences of precious and base metals, nonmetallic minerals, or energy minerals. Favorable sites for mineralization in the study area might be expected in the following generalized geologic settings: metasedimentary rocks that could contain contact-zone metasomatic replacement deposits; (2) injection pegmatites that could contain deposits of metallic or radioactive elements; (3) leucocratic granitoid rocks that could contain disseminated deposits of metals, radioactive elements, or rare-earth elements; (4) quartz veins or other vein-type deposits that result from hydrothermal mineralizing systems; and (5) mylonitic rock and crushed, sheared, and fractured rock of fault zones where mineralizing systems may have produced deposits of metallic and nonmetallic elements. Our examination of rocks within the Cactus Spring Roadless Area suggests that these generalized geologic environments have not been the sites of large-scale mineralization.

Contact metasomatic environments.-Metasedimentary pods and bodies that are associated with plutonic rocks of the Cactus Spring Roadless Area provide potential sites for metallic mineralization by contact metasomatism (Elliot, 1982). Elsewhere in the Santa Rosa Mountains, occurrences of tungsten and gold have been identified in skarn-type or tactite-type settings along the contact zones between metasedimentary and plutonic rocks (fig. 2, sites 4,5). No other metallic minerals have been reported from these settings. Metasedimentary rocks are abundant in parts of the roadless area; however, we did not observe evidence of mineralization within these rocks, or along contacts where they have been intruded by granitoid rocks. Our streamsediment geochemical survey identified elevated values for tin and molybdenum in three samples (fig. 2 , sites CS-08, CS25 , and CS-32) from drainage basins that are underlain by metasedimentary rocks and associated plutonic rocks. Although tin and molybdenum can be associated with tungsten in tactite-type mineral occurrences, tungsten was not detected in these or any other stream-sediment samples from the Cactus Spring Roadless Area.

Asbestos, in the form of the metamorphic calciummagnesium-silicate mineral tremolite, has been reported from the Sante Rosa Mountains (Tucker and Sampson, 1945; Murdoch and Webb, 1956, p. 44) and from the study aree (Wright, 1946). Asbestiform tremolite usually occurs in metamorphosed dolomite, typically along intrusive contacts between the metacarbonate rock and granitoid rock. In the Cactus Spring Roadless Area, we did not observe the "massive actinolite zone" identified by Wright (1946, geologic map) or the tremolite near Toro Peak (Wright, 1946, p. 11).

Pegmatitic environments.-Lenses and veins of pegmatite that occur locally within the Cactus Spring Roadless Area provide potential sites for occurrences of metallic elements, rare-earth elements, or radioactive elements. In the Temescal district, about $55 \mathrm{mi}$ west of the Cactus Spring Roadless Area, tin has been reported from pegmatitic quartz-tourmaline veins in granitoid rocks generally similar to those in the roadless area in the lower and upper plates of the Palm Canyon fault (Gray, 1966). Elsewhere in the Santa Rosa Mountains, beryl (the chief beryllium-bearing mineral) has been reported from quartzose pegmatite veins at the Santa Rosa prospect near the Garnet Queen Mine (California Division of Mines, 1960, unpublished report on mineral deposits of Riverside County). At the Pala district in northern San Diego County, about $35 \mathrm{mi}$ westsouthwest of the study area, lithium, rare-earth elements, and gemstones have been extracted from pegmatite veins that occur in crystalline rocks generally similar to those in the study aree (Jahns and Wright, 1951; Murdoch and Webb, 1956). Pegmatite lenses and veins are not common in the roadless area, and we observed no evidence of mineralization in the pegmatites that we examined. Moreover, our streamsediment geochemical survey did not identify significant geochemical anomalies for metallic, nonmetallic, rare-earth, or radioactive elements, although background values for tin in the roadless area and elsewhere in the Santa Rosa Mountains appear to be relatively high and may be related to pegmatite veins and pegmatitic phases of the granitoid rocks.

Disseminated metals in granitoid rocks.-Granitoid rocks within the Cactus Spring Roadless Area provide potential sites for disseminated deposits of metallic or rareearth elements. However, the petrology and intrusive setting of most of these plutonic rocks differs from plutonic rocks elsewhere that have produced disseminated-mineral deposits (for example, copper- and molybdenum-porphyry deposits; occurrence models for disseminated-mineral deposits are discussed by Cox, 1982, Theodore, 1982, and Ludington, 1982). In the Cactus Spring Roadless Area we did not observe textural and petrologic features that characterize porphyrymetal deposit types; we also did not observe evidence indicating that disseminated metals might be present (extensive zones of alteration, oxidation, or staining, or zones of rock containing disseminated native metals or metallic sulphides).

Bodies of leucocratic, garnetiferous two-mice monzogranite in the upper and lower plates of the Palm Canyon fault are similar to rocks elsewhere in the western United States that are characterized by elevated abundances of tin, rare-earth elements, and radioactive elements (see the discussion of tin granites by Taylor, 1979, p. 87-115). Our stream-sediment geochemical survey indicates that two-mica leucogranite in the study area does not have anomalous abundances of these elements.

Vein and replacement environments.-Granitoid and metasedimentary rocks within the Cactus Spring Roadless Area are potential sites for hydrothermal veins or replacement bodies containing occurrences of metals. However, in the rocks we examined, we did not observe direct evidence for these types of mineralizing systems (for 
example, surficial evidence such as extensive quartz-vein networks, iron- or copper-stained rock or gossans, alteration zones, concentrations of metallic ore minerals in veins). Mylonite and fault-zone environments.-Metallic and nonmetallic mineralization could have occurred during episodes of ductile and brittle deformation that affected rocks in the Cactus Spring Roadless Area. Ductile squeezing and flattening (mylonitization) probably took place at crustal levels where physical and chemical conditions could have allowed for mobilization of metallic and nonmetallic elements, accompanied by concentration of these elements into veins or disseminated occurrences within the mylonitized granitoid and metasedimentary rocks. Brittle deformation associated with low-angle faulting produced zones of crushed, sheared, and altered rock that probably are permeable enough to have allowed circulation of mineralizing fluids had they been available. We did not observe evidence of metallic or nonmetallic mineralization in rocks affected either by ductile deformation (mylonitization and intense foliation) or by brittle deformation (low-angle faults and associated zones of crushing, shearing, gouging, fracturing, and alteration). Moreover, our stream-sediment geochemical survey did not identify significant metallic or nonmetallic anomalies in drainage basins underlain by deformed rocks.

\section{Placer deposits}

Placer mining has not occurred in the Cactus Spring Roadless Area historically; however, sand and gravel deposits, including younger alluvial deposits as well as dissected older deposits, provide potential sites for placer accumulations of precious metals, radioactive minerals, or minerals containing rare-earth elements. We obtained numerous geochemical samples of fresh sediment deposited by active streams; however, none of these samples provides geochemical evidence of placer accumulations, and none of the stream drainages contains large amounts of alluvial fill that would provide extensive sites for large placer deposits. We did not sample the older gravel units and thus have not evaluated these gravels as a potential placer resource; however, panned-concentrate fractions from stream-sediment sites adjacent to areas underlain by older gravel deposits do not have anomalous elemental abundances.

\section{Nonmetallic resources}

Sand and gravel deposits and granitic rocks in the Cactus Spring Roadless Area provide possible sources of aggregate and riprap for construction uses, although deposits of sand and gravel are thin and limited in extent. Granitic rock for the production of crushed aggregate, decomposed granite, and riprap is abundant.

Bodies of marble (metamorphosed limestone and dolomite) that occur in the upper and lower plates of the Palm Canyon fault are possible sources of (1) lime and magnesia for industrial and manufacturing applications, and (2) crushed aggregate and construction stone. The metacarbonate bodies vary in thickness, lateral continuity, mineralogic and chemical composition, and purity. Some marble units are monolithologic, and are so thick and laterally continuous that they can be mapped as discrete units (fig. 2, unit mc); other marble outcrops consist of discontinuous layers and lenses that are interlayered complexly with schist, gneiss, and metaquartzite (fig. 2 , parts of unit ms). Some lenses and bodies of marble are white to light gray, and are relatively pure high-calcium marble. Other marble layers and bodies have varying amounts of magnesium, culminating in brownish-colored dolomite having high magnesium content. Impurities such as calc-silicate minerals (garnet, tremolite, actinolite), chert (silica), and iron carbonate occur in some marble bodies, although many appear to be free of these impurities.

\section{GEOCHEMISTRY}

A reconnaissance geochemical survey of stream sediment in the Cactus Spring Roadless Area was conducted for 32 major, minor, and trace elements to identify any spatial variations in stream-sediment chemistry that might reflect local concentrations of ore minerals. Two samples of sandy stream alluvium were collected from each of 33 sample sites within the study area (fig. 2): a bulk-sediment sample, and a panned-concentrate sample rich in heavy minerals. The results of the geochemical survey are discussed by Matti and Cox (1984). The U.S. Geological Survey conducted a more extensive stream-sediment geochemical survey in the Santa Rosa Mountains during a mineral resource study of lands that surround the Cactus Spring Roadless Area (D. Madden, unpubl. data, 1983). Analytical data from the broader-based Santa Rosa Mountains study reinforce interpretations presented herein.

The patterns of chemical composition determined by the stream-sediment geochemical survey of the Cactus Spring Roadless Area do not indicate significant large-scale mineralization. Few elemental values are anomalous with respect to the average geochemical background for the study area; instead, most of the analyses fall within ranges that are reasonable for nonmineralized plutonic and metasedimentary rocks and derivative stream sediment. Geochemical evidence thus is compatible with geologic evidence: both reconnaissance techniques suggest that largescale deposits of metallic or nonmetallic minerals probably do not occur in the Cactus Spring Roadless Area.

\section{Radioactive elements, rare-earth elements, and transition metals}

Anomalous or elevated values for uranium, thorium, yttrium, lanthanum, beryllium, and boron were detected in panned-concentrate samples from localities scattered throughout the Cactus Spring Roadless Area (uranium, 20, 26, 21 , and 24 ppm (parts per million) at sites CS-02, CS-08, CS09, and CS-26; thorium, $500 \mathrm{ppm}$ at site CS-14 and $200 \mathrm{ppm}$ at sites CS-15, CS-17, and CS-28; yttrium, $1500 \mathrm{ppm}$ at site CS-02; lanthanum, greater than $2000 \mathrm{ppm}$ at several localities; beryllium, $15 \mathrm{ppm}$ at site CS-27; and boron, 200 ppm at sites CS-11, CS-28 and CS-33; see fig. 2 for sample locations). The anomalies are small in magnitude, and probably do not reflect local concentrations of these elements in ore minerals. Instead, they probably occur in rock-forming non-ore minerals like sphene, zircon, apatite, tourmaline, allanite, and muscovite that we have observed in outcrops and in thin sections of the crystalline rock units. The abundance and chemical composition of these accessory minerals can vary with different rock types from place to place within the study area, and these variations probably account for higher-than-average values of radioactive elements, rare-earth elements, and transition metals that occur in some drainages. Two rock types within the Cactus Spring Roadless Area are most likely to have higher background levels for these elements: (1) siliceous, leucocratic monzogranite that locally is garnetiferous and pegmatitic and that locally contains both muscovite and biotite; and (2) pegmatite veins that crosscut the granitoid and metasedimentary rock units.

\section{Metallic elements}

Tungsten and pathfinders for tungsten.-Because tungsten-bearing tactite occurs elsewhere in the Santa Rosa Mountains, the results of the geochemical survey could have bearing on the distribution of undiscovered tungsten occurrences within the Cactus Spring Roadless Area. Tungsten was not detected in bulk-sediment or pannedconcentrate samples collected within the roadless area (lower detection limit in bulk-sediment and panned-concentrate media $=50$ and $100 \mathrm{ppm}$, respectively). However, analytical results from the adjacent Santa Rosa Mountains investigation show that tungsten values ranging from $100 \mathrm{ppm}$ to $500 \mathrm{ppm}$ were detected in panned-concentrate fractions from several localities scattered throughout the Santa Rosa Mountains (D. Madden, unpubl. data, 1983). These tungsten occurrences include two panned-concentrate samples collected adjacent to the Cactus Spring Roadless Area (fig. 2, localities SR-101 and SR-102, $200 \mathrm{ppm}$ and $300 \mathrm{ppm}$, respectively). Thus, although tungsten was not detected in the roadless area, the 
metal has been identified in stream sediments elsewhere in the Santr Rosa Mountains. These stream sediments were derived from calcareous metasedimentary rocks and associated granitoid rocks-rock types similar to those that crop out in the roadless area in the lower and upper plates of the Palm Canyon fault.

Molybdenum, tin, copper, and gold can be associated with tungsten in some deposit types (hydrothermal veins and tactite bodies). Localities CS-08, CS-25, and CS-32 (fig. 2) are in drainage basins underlain by metasedimentary and granitoid rocks that are possible sites for tactite-type tungsten occurrences, and samples from these localities contain elevated values for tin and molybdenum. Although these elements are known to be pathfinders for tungsten occurrences in other regions, results from the Santa Rosa Mountains geochemical survey indicate that in the lower and upper plates of the Palm Canyon fault, tungsten appears to be a pathfinder for itself: where tungsten was detected in stream sediments from drainage basins that might contain tactite-bearing metasedimentary rocks, tungsten in the stream sediments generally is not associated with elevated values of tin and molybdenum. This relationship suggests that tin and molybdenum in the Cactus Spring Roadless Area are not pathfinders for tungsten but instead have a separate source.

Tin-molybdenum-niobium association.-At most of the 33 sample localities in the Cactus Spring Roadless Area, tin, molybdenum, and niobium do not occur together in a systematic way. However, in panned-concentrate fractions from seven localities in the central and southeastern part of the roadless area (fig. 2, localities CS- 08 , CS- 09 , CS-23, CS24 , CS-25, and CS-26), tin, molybdenum, and niobium form a distinctive geochemical association. Not only do these elements occur together consistently at these seven localities, but their values here are the highest detected in the geochemical survey (maximum values: tin, $100 \mathrm{ppm}$, molybdenum, $70 \mathrm{ppm}$, niobium, $200 \mathrm{ppm}$ ). The consistent association of these elements suggests that stream sediment at the seven localities was derived from bedrock having a unique geochemical signature.

Although our studies are not detailed enough to document the actual source(s) for the tin-molybdenumniobium association, a likely source can be traced to rocks in the upper plate of the Martinez Mountain fault. Six of the seven samples containing this association are from streams that either drain the Martinez Mountain terrane exclusively (samples CS-12 and CS-26), or that ultimately have their headwaters in this terrane even though they also may contain sediment derived from beneath the Martinez Mountain fault (samples CS-08, CS-09, CS-23, CS-24). Only one of the seven localities (CS-25) sampled stream sediment derived exclusively from metasedimentary and granitoid rocks beneath the Martinez Mountain fault. Analytical data from the more extensive Santa Rosa stream-sediment survey (D. Madden, unpubl. data, 1983) also indicate that samples derived from the Martinez Mountain terrane commonly display the tin-molybdenum-niobium association-although this association locally occurs in stream-sediment samples derived from the lower and upper plates of the Palm Canyon fault. Thus, analytical data from both the Cactus Spring Roadless Area and from surrounding iands suggest that a geochemical contrast exists between rocks in the upper plate of the Martinez Mountain fault and structurally lower rocks; this contrast is recognizable on a regional basis.

The tin-molybdenum-niobium association in the Cactus Spring Roadless Area could reflect one or both of the following sources: (1) weak or incipient metallic mineralization that has occurred within bedrocks drained by the streams, or (2) elevated values for these metals in rockforming non-ore minerals that commonly occur in granitoid rocks. Whatever their source, the tin and molybdenum values are low (100 ppm tin, $70 \mathrm{ppm}$ molybdenum) relative to values detected in areas where mineralization has been documented. Although we cannot document the actual source for the tinmolybdenum-niobium suite, we believe the association most likely can be traced to rock-forming non-ore minerals like sphene and magnetite rather than to local concentrations of metallic ore minerals. Sphene is abundant in granodiorite of the Martinez Mountain terrane.

Based on analytical results from the Cactus Spring Roadless Area as well as results from the Santa Rose Mountains geochemical survey, we view the tin-molybdenumniobium signature as background rather than as a signal indicating metallic mineralization. This interpretation is based on two factors: (1) the tin-molybdenum-niobium suite does not characterize local areas where mineralization might be expected to concentrate, but instead is widespreac geographically; and (2) the range of metallic values does not vary much from background levels. By this interpretation, background levels for tin within panned-concentrate samples derived from the Martinez Mountain terrane are approximately 70 to $100 \mathrm{ppm}$; background levels for molybdenum are approximately 30 to $50 \mathrm{ppm}$.

Taylor (1979, p. 88-100) states that some granitoid rocks having high background levels for tin in rock-forming non-ore minerals are associated with tin deposits or with other metallic deposits. Thus, the tin-molybdenum-niobium association in the Cactus Spring Roadless Area, if related to rock-forming minerals like sphene and magnetite, may be signalling that a primary granitoid system exposed in the Martinez Mountain terrane was enriched in these metals and produced metallic mineral occurrences containing tin and molybdenum. However, we did not observe evidence for these metallic occurrences in rocks of the roadless area.

Tin in the Palm Canyon terrane.-Elevated values for tin occur in several panned-concentrate samples derived from granitoid rocks in the lower plate of the Palm Canyon fault (localities CS-01, CS-10, CS-11, CS-19, CS-20, CS-21, values ranging between 50 and $70 \mathrm{ppm}$ ). In some of these samples, tin is accompanied by elevated values for boron, niobium, yttrium, lanthanum, and uranium. We interpret these tin values as higher-than-average background for rocks that include pegmatite veins and leucocratic garnetiferous monzogranite that locally contains muscovite.

\section{GEOPHYSICS}

An aerial magnetic survey of the Cactus Spring Roadless Area was flown in 1981 (U.S. Geological Survey, 1982). The data have been analyzed by $H$. W. Oliver (unpub. data). The airborne magnetic survey measured variations in the total intensity of the earth's magnetic field over the Cactus Spring Roadless Area and vicinity. Slight variations in magnetic intensity are caused by uneven distribution of ironrich minerals in rocks at or near the earth's surface. Therefore, a magnetic survey can help identify concentrations of iron-rich minerals or other minerals that may be associated with deposits of iron ore. The magnetic patterns and anomalies within the study area are typical for the kinds of crystalline rocks exposed here, and there is no aeromagnetic evidence for mineralization within the Cactus Spring Roadless Area.

The aeromagnetic map (U.S. Geological Survey, 1982) is characterized by unusally low magnetic relief. The largest magnetic high is only about 80 gammas, and occurs over the south flank of Sheep Mountain. A small, broad magnetic low of about 20 gammas occurs directly northeast of the main ridge of the Santa Rosa Mountains, and is a dipole effect caused by the topography. Otherwise, magnetic variations over the granitoid rocks that make up the balance of the roadless area are even smaller ( \pm 10 gammas), and indicate that significant concentrations of magnetic iron-ore minerals (such as magnetite and pyrrotite) or buried mafic rocks of possible economic significance probably are not present in the roedless area.

A regional gravity survey was made of the Cactus Spring Roadless Area and vicinity $(\mathrm{H}$. W. Oliver, unpub. data, 1983). Stations were spaced about 1 mile apart along several profiles, and about 10 additional stations were obtained at 2to 3-mile intervals by helicopter. The purpose of the limited survey was to evaluate the possible existence of unexposed bodies of metasedimentary rock or other high-density masses caught up as xenoliths within the granitoid rocks. The presence of gravity anomolies related to such unexposed rocks might indicate mineralized bodies of rock in the subsurface of the study area. 
After corrections for differences in latitude elevation, and terrain effects, gravity is nearly constant throughout the Cactus Spring Roadless Area. A small residual gravity low of a few mGal is associated with strongly mylonitized granitoid rocks that occur in the vicinity of the Palm Canyon fault. The breadth of the anomaly indicates that the belt of intense mylonitization extends for several miles into the Earth's crust.

Magnetic and gravity measurements both suggest that granitoid and metasedimentary rocks within the Cactus Spring Roadless Area are relatively homogeneous. Both set of geophysical data argue against the presence of rock bodies having unusually high or low values of magnetism or density.

\section{MINING DISTRICTS AND MINERALZATION}

Personnel from the U.S. Bureau of Mines Western Field Operations Center, Spokane, Washington, studied mineral resources of the Cactus Spring Roadless Area in 1982 (Kuizon, 1983). County mining records were examined to determine claim locations, and library research was done to provide historical, geologic, and mineral resource data. Field studies included examination and sampling of claims, mines, and prospects.

\section{Prospecting history and production}

Mines, prospects, and claims examined in the vicinity of the Cactus Spring Roadless Area are located in figure 2, and are described in table 1.

No mines were active in the Cactus Spring Roadless Area in 1982, and there is no record of mineral production from the area. Twelve placer claims located for limestone occur within the study area (fig. 2, claims 1, 2, 3). These claims and several adjacent claims in Sec. $6,8,9,10$, and 11 (T. 7S., R. 5 E.; fig. 2, loc. 8) were located across a narrow belt of metacarbonate rock informally referred to in local usage and in some unpublished reports as the "Nightingale Limestone" (also known as the Beckelman-Lucas limestone deposit, named for some of the claimants). A narrow belt of marble occurs at the Helen Ann claims (reported by Wright 1946, p. 11), but we did not observe marble at any other claims in the study area. The Dolomite mine (fig. 2, loc. 6) has produced calcitic and dolomitic marble for roofing granules and decorative stone. Chemical-grade high-calcium limestone and marble occur in other claims of the Nightingale group (unpublished report on the mineral resources of Riverside County, reposited with the California Division of Mines and Geology); however, all of these claims were inactive in 1982. Claims in the study area located for limestone probably were placed to cover possible extensions of the marble deposits beyond their known or identified occurrence.

In the Santa Rosa Mountains, numerous old prospects were located for gold and tungsten between Toro Peak and the Garnet Queen mine (about $3.5 \mathrm{mi}$ west of the Cactus Spring Roadless Area). The tungsten mineral scheelite occurs in small-scale, calc-silicate tactite-skarn lenses along the contact between metasedimentary and granitic rocks. Most of the known tactite lenses are associated with a large northwest-trending metasedimentary pendant that occurs southwest of the study area; this pendant does not enter the roadless area. However, similar metasedimentary pendants intruded by granitoid rock occur within the roadless area, and two small tungsten-bearing tactite occurrences within these pendants have been identified by prospectors just outside of the roadless area (the Pigeon Creek and Miller Ranch prospects, fig. 2 , sites 4 and 5).

\section{ASSESSMENT OF MINERAL RESOURCE POTENTIAL}

Geologic, geochemical, and geophysical studies, together with an investigation of mines and prospects, indicate that the Cactus Spring Roadless Area has no demonstrated or inferred mineral or energy resources. Throughout most of the roadless area we did not observe indications of potential for these resources. However, a metasedimentary pendant that enters the roadless area from the southwest has low potential for low-grade tungsten resources in small-scale tactite-skarn occurrences. Bodies of marble (metamorphosed limestone and dolomite) crop out extensively in the northern part of the roadless area, and these rocks possibly could be used for industrial applications. These mineral resource assessments are based on the following considerations:

(1) Geologic mapping within the Cactus Spring Roadless Area revealed several geologic environments potentially favorable for metallic and nonmetallic mineralization. However, we did not observe evidence of significant mineral occurrences that might have formed in these environments.

(2) Generally low concentrations of metallic, nonmetallic, and radioactive elements, determined by chemical analyses from 33 bulk-sediment and pannedconcentrate samples, indicate that elemental.abundances fall within background ranges expected for nonmineralized granitic and metasedimentary rocks. Tin values ( 50 to 100 $\mathrm{ppm}$ ) and molybdenum values (20 to $70 \mathrm{ppm}$ ) in pannedconcentrate samples derived from granodiorite in the upper plate of tise Martinez Mountain fault reflect a tinmolybdenum-niobium association that characterizes the Martinez Mountain terrane. Values for these metals represent relatively high background probably related to rock-forming non-ore minerals like sphene and magnetite. Tin values ( 50 to $70 \mathrm{ppm}$ ) in samples derived from the lower and upper plates of the Palm Canyon fault also reflect regionally high background levels for tin.

(3) Aeromagnetic and gravity patterns do not indicate anomalous concentrations of magnetic minerals or the presence of rock bodies having anomalously high or low density.

(4) Within the roadless area, prospecting activities have been limited and short-lived, no production has been reported, and no large or small occurrences of metallic, nonmetallic, or radioactive minerals have been discovered. Several claims for limestone have been located within the study area. Numerous old claims located for tungsten and gold occur in metasedimentary rocks and associated granitic rocks adjacent to the roadless area, but no claims for metallic minerals have been located within the boundary of the area.

\section{DISCUSSION OF NONMETALLIC RESOURCES}

Sand and gravel and granitic rock

In the Cactus Spring Roadless Area, deposits of sand and gravel provide possible sources of aggregate and riprap for construction uses. However, both younger and older deposits of alluvium are thin and limited in areal extent. Thick, extensive, and easily accessible deposits of sand and gravel occur in the Coachella Valley (fïg. 1); local sources of sand and gravel occur adjacent to the roadless area in the vicinity of Pinyon Flat. Granitic rocks provide possible sources of crushed or decomposed aggregate and riprap. However, granitic rocks of equal quality and better accessibility are widespread in the Santa Rosa and San Jacinto Mountains.

\section{Metacarbonate rocks}

Bodies of marble (metamorphosed limestone and dolomite) that occur in the upper and lower plates of the Palm Canyon fault are possible sources of (1) crushed aggregate for roofing granules, decorative stone, and road base; (2) riprap and building stone for construction purposes; and (3) lime for cement and chemicals, and lime and magnesium carbonate for industrial and manufacturing applications. We have not assessed the quality and quantity of carbonate-rock resources present in the Cactus Spring Roadless Area, nor have we identified which marble bodies are suitable for specific industrial applications (see Bowen and others, 1973, for a discussion of the types and uses of limestone-dolomite resources). However, we have noted the geologic features of marble units within the roadless area, 
and we have summarized what is known about the grade and quality of carbonate rocks that occur in prospects adjacent to the area.

Depending on their extent and quality, the different kinds of marble could be used for different purposes. All the marble units could be used for various kinds of crushed and quarried aggregate and stone. High-calcium marble possibly could be exploited for portland cement and for the manufacture of chemicals, and some magnesium-calcite marbles could be used for smelter flux. Because the metacarbonate units have variable composition, quality, thickness, and extent, and because many carbonate layers are associated with non-carbonate metasedimentary rocks, the outcrop belt of marble would have to be mapped and sampled carefully in order to evaluate the quantity and quality of specific resources.

The possible resource value of metacarbonate rocks within the Cactus Spring Roadless Area is variable, and will depend on the specific application of the marble commodity. The physical characteristics and variable composition of many of the marble bodies may preclude their use except for crushed aggregate and building stone. Alternatively, the physical characteristics and composition of some of the marble bodies may allow them to be exploited for hightechnology or high-demand applications like portland cement, chemicals, or smelter flux.

The resource value of carbonate rocks that occur within the Cactus Spring Roadless Area must be evaluated within the context of anticipated needs nearby and farther afield, and within the context of carbonate-rock resources identified and developed elsewhere. Local demand for crushed and quarried carbonate aggregate can be met by nearby occurrences of marble at the Dolomite mine, at other claims within the Nightingale group, and at marble deposits in the Whitlock claim $6 \mathrm{mi}$ west of the study area (Brown, 1980). An abundant alternative source of crushed and quarried noncarbonate aggregate is provided by granitic rock outside the roadless area. Farther afield, demand for lime used in portland cement and other industrial applications could arise from urban expansion in the Coachella Valley and from expanding urban centers throughout southern California. Regional demand for carbonate-rock products historically has been met by deposits of carbonate rock located elsewhere in southern California (carbonate-rock resources in the San Jacinto Mountains, in the Mojave Desert province, and elsewhere in southern California are discussed by Bowen and others, 1973, Brown, 1980, Gray and Bowen, 1980, and Gray, 1962). The fact that carbonate deposits within the Cactus Spring Roadless Area previously have not been developed may reflect the physical setting and geologic character of the deposits, high transportation and development costs, lack of abundant water, or insufficient market demand.

\section{DISCUSSION OF TUNGSTEN POTENTIAI}

A pendant of metasedimentary rock in the southwestern part of the roadless area has low potential for low-grade tungsten resources in isolated, small-scale tactiteskarn bodies. The potential is low for three reasons:

(1) Geologic setting.-We examined the rocks of this pendant along several traverses, and observed that the geologic setting generally is not conducive to large-scale mineralization by the metasomatic processes that produce skarn-type tungsten deposits. The metasedimentary body consists mostly of biotite schist, gneiss, and phyllite; the body contains only minor calcareous phyllite and thin discontinuous layers of metacarbonate rock that would be potential sites for skarn mineralization. Thus, any undiscovered lenses or bodies of tungsten skarn within this metasedimentary pendant are likely to be small.

(2) Geochemical evidence.-We collected four streamsediment samples from drainages that contain outcrops of the metasedimentary pendant. None of these samples contained detectable tungsten, or anomalous values for metallic elements like tin and molybdenum that commonly are geochemical pathfinders for tungsten or occur in association with that metal.
(3) Analogy with identified occurrences.-The Pigeon Creek tungsten prospect (loc. 4 , fig. 2 and table 1) occurs at the northwestern edge of the metasedimentary pendant, just outside the roadless-area boundary. Here, tungsten occurs in a small-scale tactite occurrence that contains no resources. The Miller Ranch prospect (fig. 2, loc. 5) and Garnet Queen Mine (3.5 mi west of the roadless area) contain similar lenses of tungsten-bearing tactite that contain no resources. Using previous experience in the Santa Rosa Mountains as a guide, it is unlikely that large-scale mineral occurrences containing tungsten resources exist in the metasedimentary pendant containing the Pigeon Creek prospect.

Based on these three arguments, we conclude that the metasedimentary pendant containing the Pigeon Creek prospect has low potential for low-grade tungsten resources in small-scale tactite-skarn bodies. Any undiscovered mineral occurrences that might exist in this area probably are not important mineral deposits; instead, these occurrences probably will be similar to those at the Pigeon Creek and Miller Ranch prospects and the Garnet Queen mine.

Elsewhere in the Cactus Spring Roadless Area and in the Santa Rosa Mountains, marble and calcareous metasedimentary rocks that have been intruded by granitoid rocks provide geologic environments where tactite-type tungsten mineralization might be expected. Although our stream-sediment geochemical survey of the roadless area did not detect tungsten, a similar survey conducted by the U.S. Geological Survey for adjacent lands indicates that tungsten locally occurs in metasedimentary rocks of the lower and upper plates of the Palm Canyon fault (D. Madden, unpubl. data, 1983). Adjacent to the roadless area we have identified two zones of low potential for tungsten (fig. 2). However, even though a generalized occurrence model for tungsten mineralization can be recognized in rocks of the Cactus Spring Roadless Area, we did not observe any indications of tungsten potential in metasedimentary rocks other than those having low potential.

\section{REFERENCES CITED}

Bowen, O. E., Gray, C. H., Jr., and Evans, J. R., 1973, The mineral economies of the carbonate rocks: limestone and dolomite resources of California: California Division of Mines and Geology Bulletin 194, $60 \mathrm{p}$.

Brown, A. R., 1980, Limestone deposits of the Desert Divide, San Jacinto Mountains, California, in Fife, D. L., and Brown, A. R., eds., Geology and mineral wealth of the California desert: Santa Ana, California, South Coast Geological Society, p. 284-293.

1981, Structural history of the metamorphic, granitic, and cataclastic rocks in the southeastern San Jacinto Mountains, in Brown, A. R., and Ruff, R. W., eds., Geology of the San Jacinto Mountains: South Coast Geological Society Annual Field Trip Guidebook No. 9, p. 100-138.

Cox, D. P., 1982, A generalized empirical model for porphyry copper deposits, in Erickson, R. L., compiler, Characteristics of mineral deposit occurrences: U.S. Geological Survey Open-File Report 82-795, p. 27-32.

Dokka, Roy K., and Frost, Eric G., 1979, Fission-track ages from the Santa Rose mylonite and its protolith and their relation to the cooling history of the southern California batholith: Geological Society of America Abstracts with Programs, v. 10, no. 3, p. 103.

Elliot, J. E., 1982, Model for contact metasomatic tungsten/copper/gold deposits, in Erickson, R. L., compiler, characteristics of mineral deposit occurrences: U.S. Geological Survey Open-File Report 82-795, D. 49-54.

Fraser, D. M., 1931, Geology of the San Jacinto quadrangle south of San Gorgonio Pass, California: California Journal of Mines and Geology, v. 27, no. 4, p. 494-540, map scale $1: 125,000$.

Gray, C. H., Jr., 1962, Limestone resources of southern California, Part 1: Mineral Information Services, California Division of Mines and Geology, v. 15, no. 5 , p. 1-5. 
Gray, C. H., Jr., 1966, Tin, in Mineral resources of California: California Division of Mines and Geology Bulletin 191, p. 422-425.

Gray, C. H., Jr., and Bowen, O. E., 1980, The limestone and dolomite resources of the Mojave Desert province, California, in Fife, D. L., and Brown, A. R., eds., Geology and mineral wealth of the California desert: Santa Ana, California, South Coast Geological Society, p. 150-161.

Jahns, R. H., and Wright, L. A., 1951, Gem- and lithiumbearing pegmatites of the Pala district, San Diego County, California: California Division of Mines and Geology Special Report 7A, 72 p.

Kuizon, Lucia, 1983, Mineral investigation of the Cactus Spring RARE-II Area (No. A5-188), Riverside County, California: U.S. Bureau of Mines Open-File Report MLA 25-83, 11 p.

Ludington, Steve, 1982, Granite molybdenite systems, in Erickson, R. L., compiler, Characteristics of mineral deposit occurrences: U.S. Geological Survey Open-File Report 82-795, p. 43-46.

Matti, J. C., and Cox, B. F., 1984, Geochemical map of the Cactus Spring Roadless Area, Riverside County, California: U.S. Geological Survey Miscellaneous Field Study Map MF-1650-B, scale 1:24,000.

Miller, R. H., Gastil, R. G., Anderson, P. V., Dockum, M. S., and Stevens, C. H., 1983, Uppermost Precambrian through Triassic rocks of southern and Baje California: Pacific sections, AAPG, SEG, SEPM, Program and Abstracts, 58th Annual Meeting, Sacramento, p. 114.

Miller, R. H., and Dockum, M. S., 1983, Ordovician conodonts from metamorphosed carbonates of the Salton Trough, California: Geology, v. 11, p. 410-412.

Murdoch, Joseph, and Webb, R. W. 1956, Minerals of California: California Division of Mines and Geology Bulletin 173, 452 p.
Parcel, Rodney F., Jr., 1981, Structure and petrology of the Santa Rose shear zone in the Pinyon Flat area, Riverside County, California, in Brown, A. R., and Ruff, R. W., eds., Geology of the San Jacinto Mountains: South Coast Geological Society Annual Field Trip Guidebook No. 9, p. 139-150.

Sharp, R. V., 1979, Some characteristics of the eastern Peninsula Ranges mylonite zone: Analysis of actual fault zones in bedrock, U.S. Geological Survey OpenFile Report 79-1239, p. 258-267.

Sims, S. J., 1960, Geology of part of the Santa Rosa Mountains: Stanford University, unpublished Ph.D. thesis, $87 \mathrm{p}$.

Streckeisen, A. L., 1973, Plutonic rocks: classification and nomenclature recommended by the IUGS Subcommission on the Systematics of Igneous Rocks: Geotimes, v. 18 , no. 10 , p. 26-30

Taylor, R. G., 1979, Geology of tin deposits: Amsterdam, Elsevier Scientific Publishing Company, 543 p.

Theodore, T. G., 1982, Preliminary model outline for fluorinedeficient porphyry molybdenum deposits, in Erickson, R. L., compiler, Characteristics of mineral deposit occurrences: U.S. Geological Survey Open-File Report 82-795, p. 37-42.

Tucker, W. B., and Sampson, R. J., 1945, Mineral resources of Riverside County: California Division of Mìnes, 41st Report of the State Mineralogist, 156 p.

U.S. Geological Survey, 1982, Aeromagnetic map of the Cactus Spring Roadless Area, California: U.S. Geological Survey Open-File Report 82-945.

Wright, L. B., 1946, Geology of the Santa Rosa Mountain area, Riverside County, California: California Division of Mines and Geology, 42nd Report of the State Mineralogist, p. 9-13.

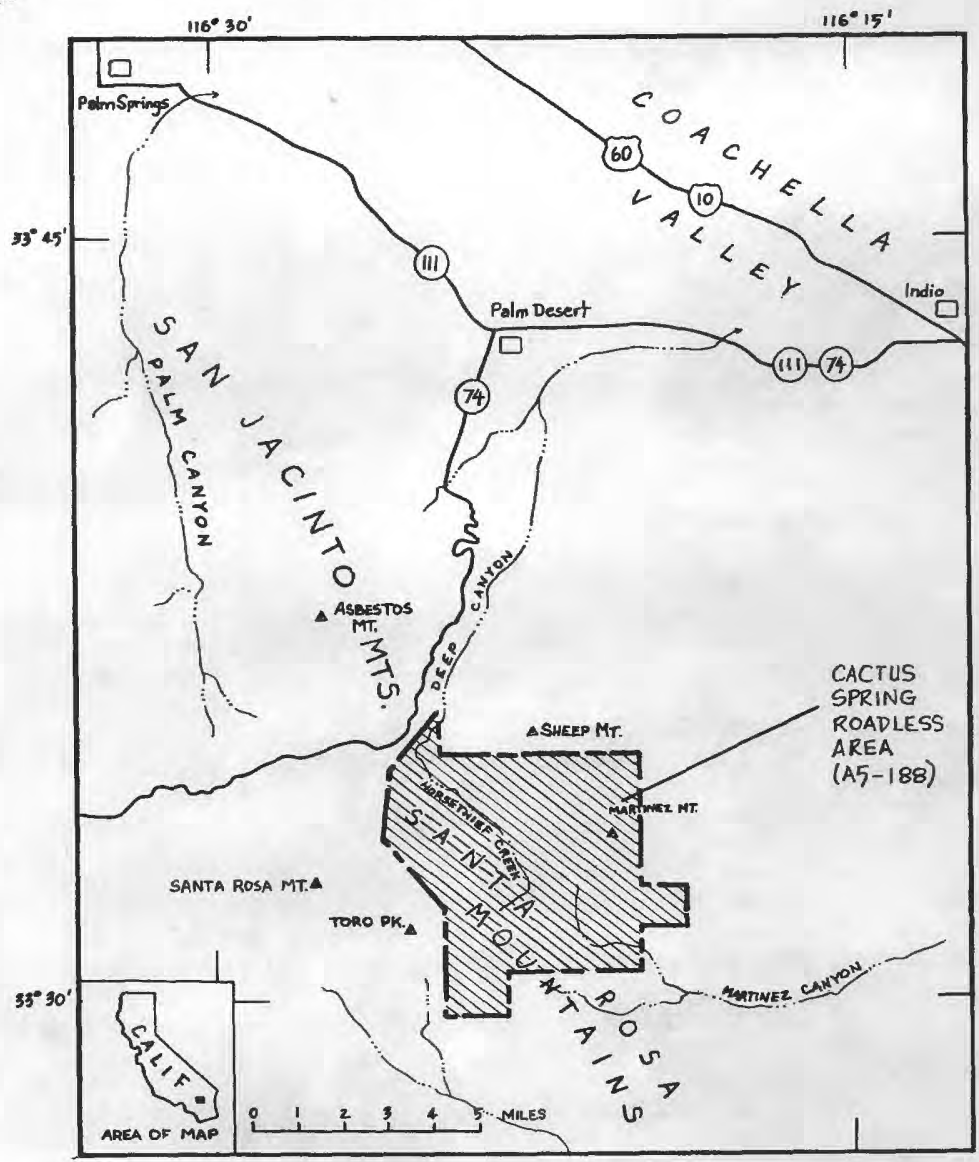

Figure 1.--Index map showing location of the Cactus Spring Roadless Area, Riverside County, Callf. 


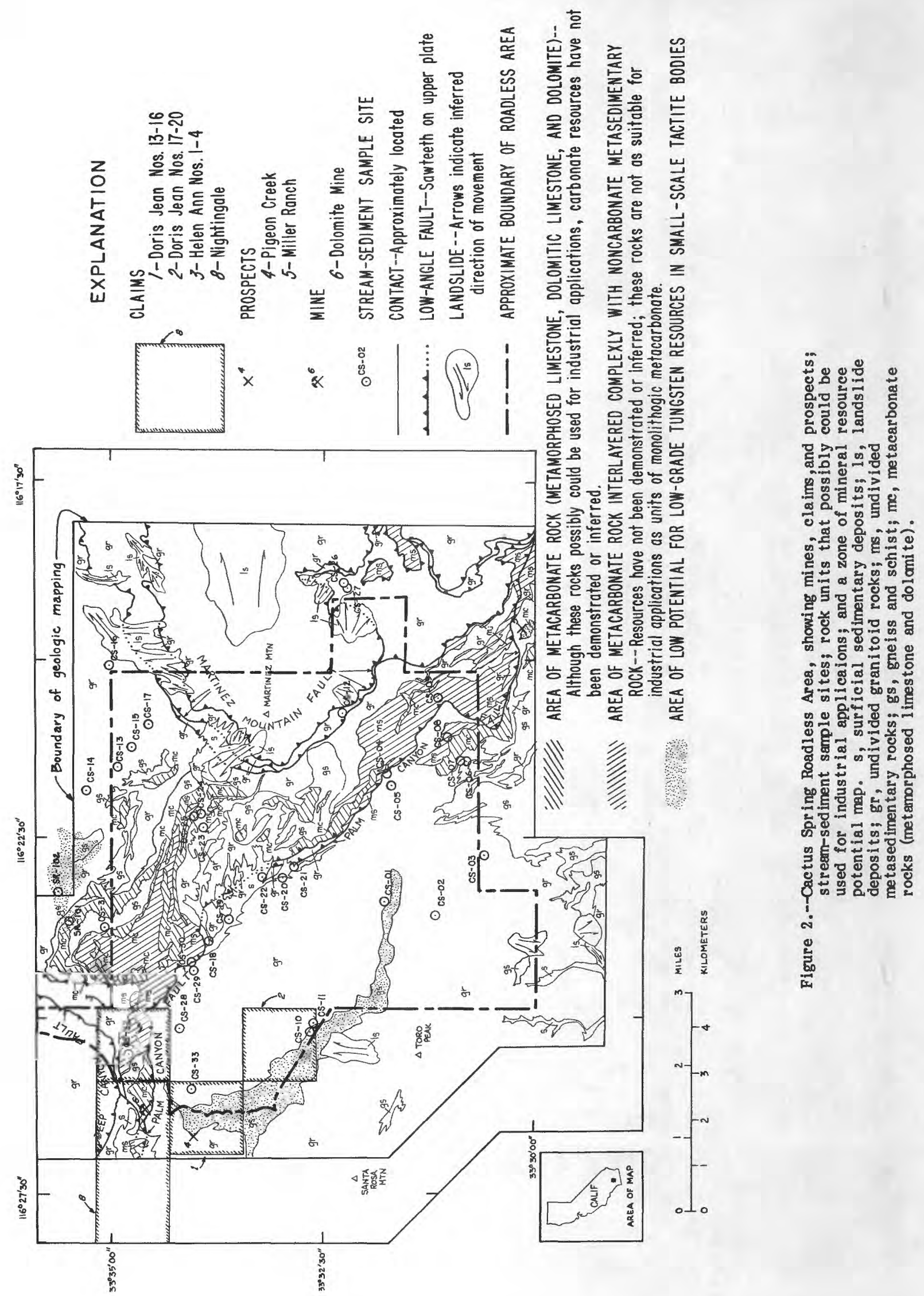




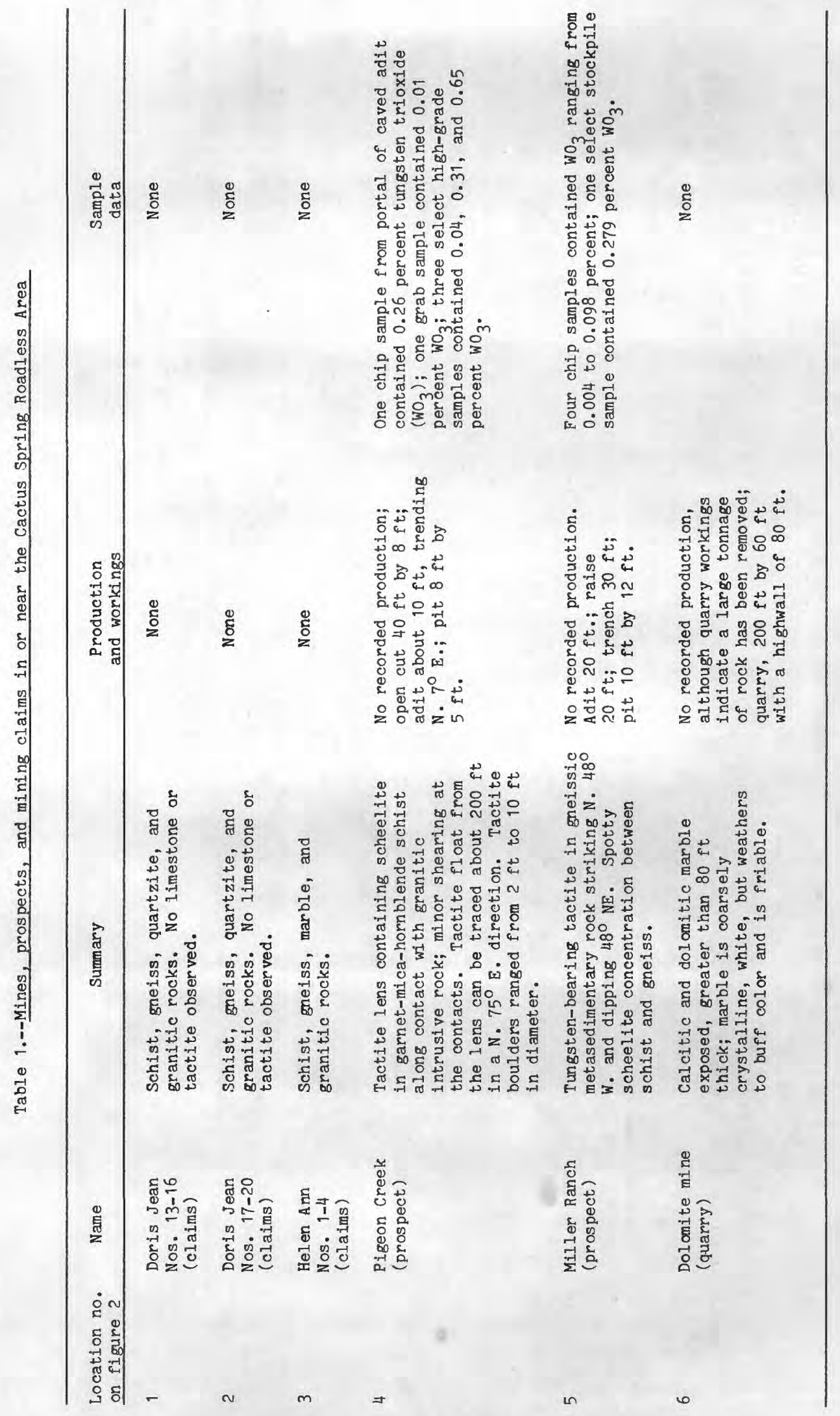

